\title{
Review of Conductive Copper Paste for c-Si Solar Cells
}

\author{
Sang Hee Lee, Doo Won Lee, and Soo Hong Lee* \\ Green Strategic Energy Research Institute, Department of Electronics Engineering, Sejong University, \\ Seoul 05006, Republic of Korea
}

\begin{abstract}
In the photovoltaic industries, the main technique of metallization is screen printing with silver pastes, due to its simple and quick process. However, the high price of silver paste is one of the barriers to the producing of low cost solar cells. Consequently, a primary target in photovoltaic research is to reduce consumption of silver paste or substitute silver with other lower cost materials. As a proper candidate, copper has been extensively investigated for that purpose by many institutes and companies, since it is less expensive than silver with similar conductivity. The plating technique has been actively researched to apply copper as a contact for solar cells. However, copper paste, which was originally developed for integrated circuit applications, has been recently attracted attention. Initially, copper paste was applied for a low temperature annealing process since copper tends to oxidize easily. Recently, a firing type copper paste was also developed which involves coating of the copper particles with a barrier layer. This paper reviews recent developments of copper pastes for the application to solar cells, and its appropriate annealing conditions for better electrical properties. Also, the light I-V characteristics of copper paste on the solar cells reported in the literature are summarized. The $20.7 \%$ of the conversion efficiency of a PERT (passivated emitter and rear totally diffused) structure solar cell demonstrates the potential of copper paste as a promising future metallization material.
\end{abstract}

(Received May 11, 2017; Accepted May 23, 2017)

Keywords: copper paste, curing atmosphere, passivated busbar, HIT solar cells

\section{INTRODUCTION}

In the photovoltaic industries, screen printing is the predominant metallization technique used for silicon based solar cells fabrication, because it is quick and simple. As a material of front contact, silver is the favorable metal since it has high conductivity and is chemically inactive. However, screen printing with silver paste is the second expensive component in cell production, after the cost of the silicon material. For this reason, reducing the amount of silver consumed per cell or replacing silver with other metal materials is a significant area of research. According to the international technology roadmap for photovoltaic (ITRPV) published in 2016, silver consumption per cell will decrease to about $40 \mathrm{mg} / \mathrm{cell}$ with the upcoming developments of pastes and screens, which is around 40\% lower than now (95 $\mathrm{mg} / \mathrm{cell})$ [1]. In particular, developing methods to replace silver with copper has been an actively researched area, since

*Corresponding Author: Soo Hong Lee [Tel: +82-2-3408-3726, E-mail: shl@sejong.ac.kr] Copyright (c) The Korean Institute of Metals and Materials the cost of copper is approximately fifty times less expensive than silver, but has a similar conductivity (silver: $1.6 \mu \Omega-\mathrm{cm}$, copper: $1.7 \mu \Omega-\mathrm{cm})[2,3]$. In order to share new information and go over the technical limitations, workshops for the metallization of crystalline silicon solar cells have been organized since the first workshop in Utrecht, Netherlands, in 2008.

Research on the application of copper contacts has been mainly carried out by using the plating technique, due to its various advantages, such as high aspect ratio and low contact resistance, which result in a high efficiency solar cell over $21 \%[2,4]$. On the other hand, the application of screen printable copper paste on solar cells has also been studied, since the process can be easily applied to the established cell production lines. One of the factors affecting the use of copper paste is that copper particles cannot be deposited directly on the emitter, since the copper atoms have a fast diffusion velocity and act as deep-level impurities in the crystalline silicon solar cell [5-7]. The copper atoms in the silicon produce generation and recombination centers and 


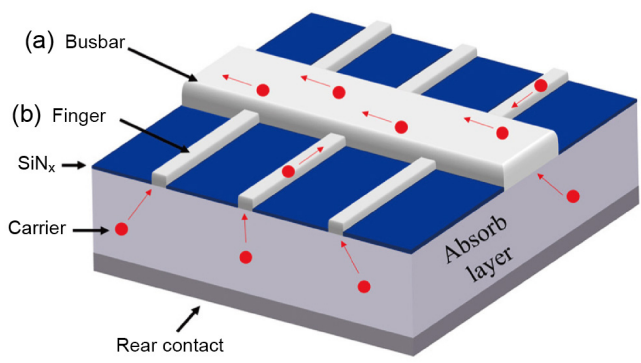

Fig. 1. Carrier collection by the screen printed silver (a) busbar and (b) finger.

degrade the minority carrier lifetime of the crystalline silicon solar cells [8,9]. Accordingly, most of the copper pastes employed on the solar cells, have been printed above the passivation layer as a busbar, which is called 'passivated busbars', while the silver paste fingers are used to contacted the silicon. Figure 1 shows a busbar and the fingers on a solar cell that were printed by silver paste. Like the fingers, the role of the busbar on the solar cell is to collect the charge carriers generated by incident light in the absorption layer. The busbar is also connected to a soldered ribbon, which is used to extract carriers out of the device. To connect a busbar with a ribbon, the busbar should be printed so that it has a width similar to that of the ribbon, which is usually $1.5 \mathrm{~mm}$ on the commercial type of solar cells. Accordingly, researchers tried to apply copper paste only for the busbar since most of the silver paste usage is for the busbar, while the fingers are still printed by using silver paste or deposited by the plating technique. Nonetheless, it is possible to apply copper paste directly on the silicon if the copper particles are coated with barrier layers in order to prevent the copper from diffusing into the silicon. Another issue with applying copper in the application to the paste form is that copper tends to oxidize easily during thermal treatment [5,10-12]. Since copper oxide shows an electrically non-conductive characteristic, it will increase the series resistance in the solar cells. To address these problem, several institutes and companies have extensively researched the methods and issues involved in applying copper paste. In this paper, we mainly discuss about research trends in the use of copper paste components. Then, the curing conditions and the results of actual copper paste applications to the silicon solar cells is mentioned.

\section{COPPER PASTE DEVELOPMENTS FOR THE C-Si SOLAR CELLS}

In the 1990s, copper paste was researched for the application on integrated circuits such as printed circuit boards. With the increase in circuit density, the properties of the copper paste needed to be improved. Those efforts were mainly focused on optimizing the size of the metal particles to enhance the density and printability of the paste $[13,14]$. Recently, copper paste research has been developed again for application of the crystalline silicon solar cells as the low cost front contact.

The performance of copper paste is generally compared to silver paste since the latter is the material predominantly used for the front metallization of the crystalline silicon solar cell. In order to apply copper paste to the solar cells, the properties of the copper paste, such as printability and solder ability, need to be similar or better than the characteristics than silver paste. One of the important components of the conventional silver paste for the front contact of the crystalline silicon solar cell is glass frits. When silver paste is used in the crystalline silicon solar cells based on the silver paste, the dielectric layer, which is usually silicon nitride $\left(\mathrm{SiN}_{\mathrm{x}}\right)$, is fired-through above $600{ }^{\circ} \mathrm{C}$, and as a result, the silver particles contact the emitter (Fig. 2(a)). Unfortunately, when the copper paste is substituted for the silver paste, the diffused copper can adversely effect on the characteristics of the solar cell, as we mentioned above. To apply copper paste to the crystalline silicon solar cells, the copper particles in the paste need to be coated with barrier layers. Then, the copper paste can be fired at a similar temperature range as the silver paste and contact the emitter (Fig. 2(b)). If they are not protected to avoid copper diffusion, the copper paste should be cured without penetrating the $\mathrm{SiN}_{\mathrm{x}}$ layer (Fig. 2(c)). The curing type copper paste, which is typically polymer based, does not need require the use of glass-frits components for the fired-through contact. Because the curing temperature of the polymer curing type copper paste is much lower than that of the firing type paste, it can be used to apply inexpensive copper electrodes to the heterojunction with intrinsic thin layer (HIT) solar cell structures, which cannot be processed using high 



Fig. 2. (a) Conventional silicon solar cell contact with silver paste, (b) contact with firing type copper paste, (c) contact with curing type copper paste and (d) contact with curing type copper paste on the HIT solar cell.

temperature annealing. Also, when copper paste is printed on the indium tin oxide (ITO) layer of an HIT solar cell (Fig. 2(d)), the ITO can acts as a diffusion barrier which prevents copper diffusion [15]. In this chapter, we considered the components of the copper pastes used for application to solar cells, categorized by according to the high or low annealing temperature of the paste.

\subsection{Copper paste for high temperature annealing}

In 2011, Applied Materials, Inc. developed a copper paste that was chemically and metallurgically similar to conventional silver paste. This allowed the $\mathrm{SiN}_{\mathrm{x}}$ layer to be fired-through by the copper paste, and putting the metal particles directly in contact with silicon (Fig. 2(b)). The copper paste was composed of a metal powder, a polymer, glass frits, a solvent and additives. The invented technique involves encapsulation of the copper-containing particles with additional layers of metal and alloys to restrict oxidation and diffusion of copper during the firing. The copper-containing particles are made with doped-copper or copper alloys, rather than pure copper particles to improve their hardness and reduce the tendency to oxidize. There are three levels of encapsulation to protect the copper particles from oxidation and diffusion. First, the copper-containing particle can be coated by oxidation barrier layers. Also, a metallization barrier layer can be used under the oxidation barrier since the oxidation layer can form an alloy with the inside material. Moreover, a diffusion barrier can directly surround the copper-containing particle for a more perfect encapsulation. The possible materials that can be used for the encapsulation layer are listed in the Table 1.

\subsection{Copper paste for low temperature annealing}

Low temperature annealing copper paste has become a promising future product since HIT solar cells have become common in the PV industry. Dow Corning has published papers and patents on a curing type copper paste, and the applicable solar cell structures [16-20]. Curing refers to as the hardening of a polymer materials by cross-linking polymer chains, and typically can be processed by heating at a low temperature, below $300{ }^{\circ} \mathrm{C}$. The copper paste consists of metal powder, solder powder (which has a melting temperature lower than that of the metal powder), a polymer, a solvent, a cross-linking agent and additives. The solder powder is comprised of at least one of a tin-bismuth $(\mathrm{SnBi})$ alloy, a tin-silver (SnAg) alloy or combinations of them. The polymer and the carboxylated-polymer is made of an epoxy resin and an acrylic polymer, respectively. The cross-linking agent (or catalyst) can be chosen from carboxylatedpolymers, dimer fatty acids and trimer fatty acids. Among the dimer fatty acids, dicarboxylic acid and monocarboxylic acid are useful for fluxing the metal powder and cross-linking the polymer. In addition, a solvent and adhesion promoter can be included as additive components. This copper paste is used to

Table 1. The possible materials of each encapsulation layer for copper-containing particles.

\begin{tabular}{c|c|c|c}
\hline Encapsulation layer & Oxidation barrier & Metallization barrier & Diffusion barrier \\
\hline Possible materials & Silver (Ag), nickel (Ni) & and zinc $(\mathrm{Zn})$ & $\begin{array}{c}\text { Nickel }(\mathrm{Ni}), \text { titanium }(\mathrm{Ti}), \text { titanium nitride (TiN), tungsten }(\mathrm{W}), \\
\text { titanium-tungsten (TiW), tungsten doped cobalt (Co:W), cobalt } \\
(\mathrm{Co}), \text { molybdenum (Mo), tantalum (Ta) and chromium (Cr) }\end{array}$ \\
\hline
\end{tabular}




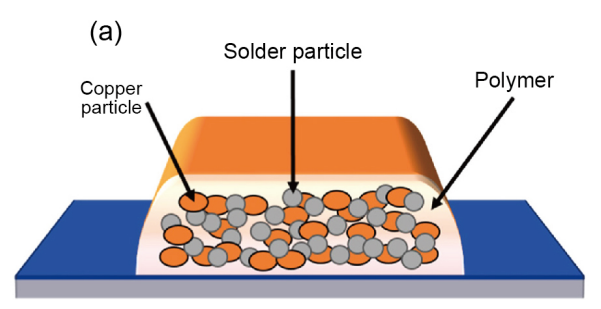

(b)



Fig. 3. Dow corning's screen printable copper paste. (a) After printing and (b) after curing.

form the busbar of a conventional crystalline silicon solar cell without the use of a fired-through process. Figure 3 shows that the printed busbar has a brown-red color due to the copper particles. After the curing process, the color of the busbar changes to grey after the curing process since the copper particles have been coated by the solder. The solar cells fabricated with the copper busbar have a higher front surface minority carrier lifetime than the cells with the silver fired-through busbar, since the covered area under the busbar is fully passivated. We discussed their detailed characteristics in Section 3.

A research group in the National Institute of Advanced Industrial and Scientific Technology (AIST) also reported a copper paste concept similar to the Dow Corning's copper paste. Their copper paste, which is called a 'copper-alloy paste', is composed of conductive metal particles, a low melting point alloy (LMPA), thermosetting polymer and solvent [21]. During the curing process, the molten LMPA particles form an alloy with the copper particles and surround the copper particles to prevent oxidation. The LMPA allows a curing process to set the temperature below $200{ }^{\circ} \mathrm{C}$ without any reductive conditions, unlike the conventional silver paste. The results of the differential scanning calorimetry (DSC) measurements showed that the melting point of the LMPA was $143{ }^{\circ} \mathrm{C}$. The peak of the DSC graph was very sharp since the LMPA had nano-level uniformity. Moreover, the copper-alloy paste showed better self-leveling and resolution than the conventional silver paste after the screen printing process on a textured silicon wafer.

The same group also evaluated the reliability of the copper electrodes, which were printed only as a busbar with using the copper paste on p-type crystalline silicon wafers [22]. The samples were evaluated by using the damp heat test (DHT) and thermal cycling test (TCT) before and after the encapsulation with a 'sandwich' structure (glass/EVA/cell/ EVA/backsheet) according to the IEC61215 standards. The results of both the DHT and TCT showed degradation of less than $5 \%$ of the initial values in the all parameters $\left(\mathrm{V}_{\mathrm{oc}}, \mathrm{J}_{\mathrm{sc}}, \mathrm{FF}\right.$, $\mathrm{P}_{\max }$, etc.) before and after encapsulation. After the DHT test, the surface of the copper electrode without encapsulation was oxidized and the oxide layer acted as a semi-passivation layer that postponed inner oxidation. Moreover, they confirmed that the copper particles in the paste did not diffuse into the silicon after an hour of annealing at $400{ }^{\circ} \mathrm{C}$, due to the polymer barrier layer. However, the vapor-deposited copper layer diffused into the silicon. They insisted that the silver fingers were the main path of copper diffusion into the silicon since $\mathrm{Cu}_{3} \mathrm{Si}$ was only detected underneath the silver finger electrodes.

Samsung Electro-Mechanics Co., Ltd. invented a copper paste with nano-particle sized copper powder, especially for substrates which cannot be used with high temperature processes (such as a transparent conductive oxide (TCO), a polymer, a glass plate and a printed circuit board) [23,24]. The average particle size of the copper was around $150 \mathrm{~nm}$, and the surfaces of the copper particles were coated with a capping material, which can be a fatty acid or fatty amine. The nano-sized copper powder can be used either solely as a metal powder or with different sizes of copper particles, such as a flake powder and a spherical powder. The flake powder has a particle size of 1-20 $\mu \mathrm{m}$ and the spherical powder has a 0.1-5 $\mu \mathrm{m}$ particle size. When the nano powder is mixed with other types of powder, it first dissolves during the annealing process and helps to establish connections between the bigger copper particles. Because of the nano-size scale effects, this copper paste can enhance conductivity. The detailed list of candidates for binders and additives is also presented in the patent. Consequently, it was reported that copper particles with $150 \mathrm{~nm}$ in size reduces the annealing temperature of the 


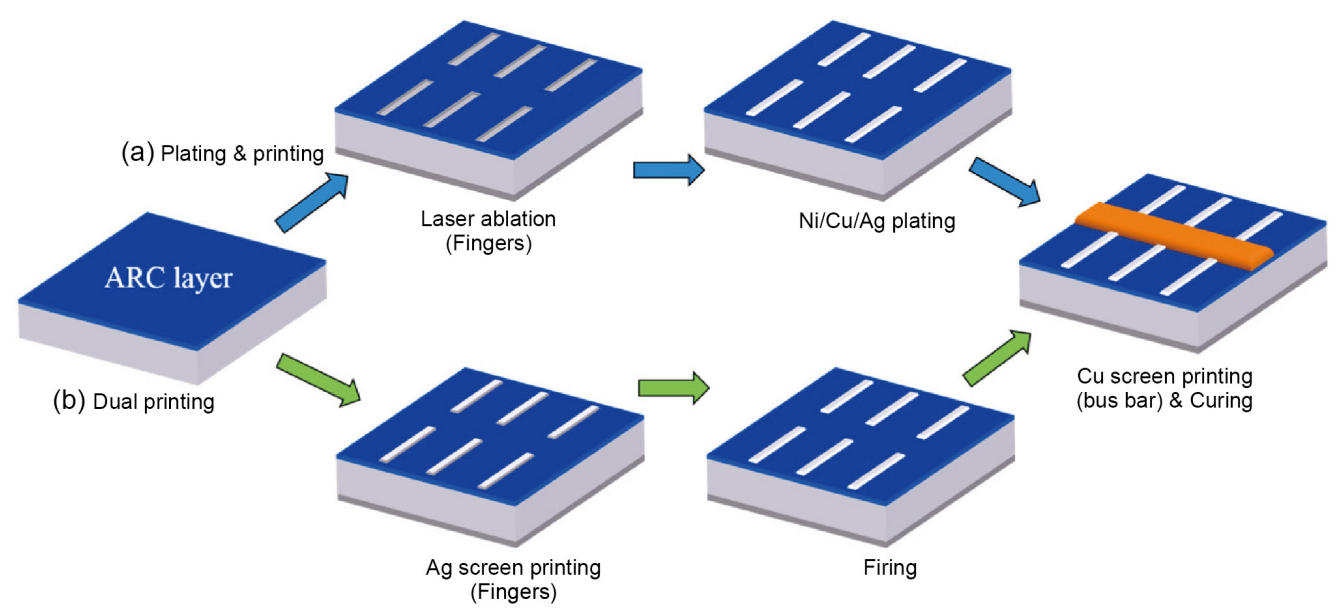

Fig. 4. Front metallization process flows for the passivated copper busbar: (a) plating \& printing, (b) dual printing.

paste and makes it possible to form electrodes at a low temperature of $200{ }^{\circ} \mathrm{C}$.

Recently, the Institute of Nuclear Energy Research (INER) reported an anti-oxidant copper paste [25,26]. The anti-oxidant copper nanoparticles were synthesized by using a wet chemical reduction process which requires copper hydroxide $\left(\mathrm{Cu}(\mathrm{OH})_{2}\right)$, polyvinylpyrrolidone (PVP) and ascorbic acid. The antioxidant copper nanoparticles were transferred to the paste form and printed onto the ITO layer of HIT solar cells, followed by low temperature annealing $\left(<300{ }^{\circ} \mathrm{C}\right)$. Compared to commercial silver pastes as a reference, the $16 \mu \mathrm{m}$ printed copper paste films showed a twofold increase in sheet resistance $(\sim 30 \mathrm{~m} \Omega$ /sq). However, the duration of the copper paste annealing was $1 / 12$ of that of silver paste. Also, the anti-oxidative ability of the paste was tested by reserving samples for 180 days in atmospheric conditions without strict nitrogen protection. The results of XRD characterization result showed no peaks of oxide impurities, which means the copper film was relatively stable against oxidation, at least at the X-ray detection level.

\section{APPLICATION OF COPPER PASTE ON C-Si SOLAR CELLS}

\subsection{Curing conditions for high electrical properties}

The curing process is carried out at a lower temperature range than the firing process, which is generally used for the conventional silver paste. Rehm thermal systems $\mathrm{GmbH}$ and
Fraunhofer Institute for Ceramic Technologies and Systems reported the effect of curing conditions on the properties of an electrode that was printed with a polymer based-copper paste $[10,27,28]$. By using an inert inline drying system, the effects of curing temperature and nitrogen percentages were studied. The temperature conditions were varied from 160 to $220{ }^{\circ} \mathrm{C}$, while the nitrogen conditions were varied from standard, medium, and to high nitrogen concentrations. A very low resistance of copper paste electrode was obtained with a high nitrogen atmosphere. The presence of nitrogen resulted in a substantial resistance difference, while the temperature showed no significant impact on resistance [28]. Experiments with different curing atmospheres also showed that the resistance of the copper paste significantly depended on the nitrogen concentration. The main reason for the reduced resistance is that the cross-linking reactions of the polymer chains, which are sensitive to the oxygen concentration, since the oxygen disturbs the linking process between the polymer chains. Accordingly, an inert curing atmosphere with a low concentration of the oxygen result in an intensified polymerization and an increase the compression of the metal particles. Another possible reason could be the restrained oxidation of the metal particles. The optimum curing duration was determined to achieve the minimum resistance and decent adhesion by increasing the processing time. Consequently, the polymer based copper paste, which is annealed by the inert curing, showed considerable improvement of the copper paste conductivity and mechanical stability. 
Table 2. Performance of various solar cell structures with the passivated copper busbar and gains compared to their reference contact.

\begin{tabular}{|c|c|c|c|c|c|c|c|c|c|}
\hline Institute & Year & Cell type & Ref. contact & $\eta[\%]$ (gain) & $\begin{array}{c}\mathrm{V}_{\mathrm{oc}}[\mathrm{mV}] \\
\text { (gain) }\end{array}$ & $\begin{array}{c}\mathrm{J}_{\mathrm{sc}} \\
{\left[\mathrm{mA} / \mathrm{cm}^{2}\right]}\end{array}$ & $\begin{array}{c}\text { FF [\%] } \\
\text { (gain) }\end{array}$ & $\begin{array}{c}\text { Annealing } \\
\text { Temp. }\end{array}$ & Ref. \\
\hline Dow corning & 2014 & p-PESC (SE) & SP*-Ag & $18.8(-0.07)$ & $640.4(+0.3)$ & 37.2 & $78.9(-0.5)$ & $\sim 250{ }^{\circ} \mathrm{C}$ & {$[16]$} \\
\hline Dow corning & 2015 & p-PERC & Plated-Ni/Cu/Ag & $20.4(+0.1)$ & $667.5(+6.1)$ & 38.7 & $79.0(+0.3)$ & $\sim 250{ }^{\circ} \mathrm{C}$ & [17] \\
\hline Dow corning & 2015 & n-PERT & Plated-Ni/Cu/Ag & $20.7(0)$ & $663.3(+4.9)$ & 39.2 & $79.5(0)$ & $\sim 250{ }^{\circ} \mathrm{C}$ & [17] \\
\hline Meiji Univ. & 2015 & n-PERT (Bifacial) & SP-Ag & $20.5(+0.7)$ & $659.0(+3.0)$ & 40.8 & $76.3(+2.0)$ & - & [29] \\
\hline Tokyo Univ. & 2012 & p-PESC (mc-Si) & SP-Ag & $16.2(+0.1)$ & $617.0(-2.0)$ & 34.3 & $76.3(+0.1)$ & $<200{ }^{\circ} \mathrm{C}$ & [30] \\
\hline
\end{tabular}

*SP: Screen printed

\subsection{Characterization of solar cells with the copper paste}

Some of research groups have attempted to apply their own copper paste to solar cells. In these studies, the copper pastes were printed as passivated busbars that required forming of busbars and fingers separately. As Fig. 4 shows, fingers only electrically contacted silicon by using either fired-through silver paste (Fig. 4(b)) or the plating of a $\mathrm{Ni} / \mathrm{Cu} / \mathrm{Ag}$ metal stack after laser ablation opening of the $\mathrm{SiN}_{\mathrm{x}}$ layer (Fig. 4(a)). Afterwards, the busbar was printed on the $\mathrm{SiN}_{\mathrm{x}}$ layer and partially contacted the fingers, followed by a curing process at a temperature below $250{ }^{\circ} \mathrm{C}$. Since the busbars did not directly contact the silicon, the recombination region under the busbars was removed. The light I-V performances of the solar cells with the copper paste busbar are summarized in Table II. To produce the reference cells for comparison, either the screen printed silver paste contacts or the $\mathrm{Ni} / \mathrm{Cu} / \mathrm{Ag}$ plated contacts were wholly used for the busbars and fingers. Generally, the reduced recombination on the front side contributed to an increase in open circuit voltage $\left(\mathrm{V}_{\mathrm{oc}}\right)$ compared to the cells with the non-passivated busbar.

Dow Corning and IMEC evaluated the characteristics of various cell structures after applying their own low temperature $\left(\sim 250{ }^{\circ} \mathrm{C}\right)$ copper paste for the passivated busbars. The research group confirmed a slight increase in $\mathrm{V}_{\text {oc }}(0.3 \mathrm{mV})$ with an industrial level passivated emitter solar cell (PESC) by reducing the recombination region under the busbars. Compared to a conventional silver paste solar cell, the passivated copper busbar solar cell had a lower average fill factor (FF) due to the higher lateral resistivity of the copper busbar. However, the busbar resistivity did not have an effect on FF in the module level performance since most of the lateral current flowed through the conductive soldered tab.
This group also evaluated combinations of printable conductive copper paste with higher efficiency solar cell structures, such as passivated emitter and rear cell (PERC) and passivated emitter and rear totally diffused (PERT). By applying a copper paste busbar with a plating and printing process, as depicted in Fig. 4(a), both structures exhibited an improved $\mathrm{V}_{\text {oc }}$ of $6.1 \mathrm{mV}$ and, $4.9 \mathrm{mV}$, respectively, and the PERC structure especially exhibited $0.1 \%$ higher median conversion efficiency than the reference group. Also, the FF of the passivated busbar cells were increased, since the laser ablation and the nickel silicide decreased the shunt resistance of the fully plated cells. With respect to of the current density, even though there was almost no difference in the series resistance of the printed busbar and the plated busbar, the passivated busbar cell had a slightly lower value, since the plated busbar had a higher aspect ratio (fine line width).

K. Nakamura et al. at Meiji University applied copper paste to an n-type bifacial PERT cell and successfully obtained over $20 \%$ efficiency by enhancing $\mathrm{V}_{\mathrm{oc}}$ and $\mathrm{FF}$ compared to a silver printed cell. Also, S. Yoshiba et al. at Tokyo University compared the I-V performances of a multi-crystalline silicon solar cell after printing a low melting point alloy (LMPA) copper paste. Although $\mathrm{V}_{\mathrm{oc}}$ was decreased, copper printed cell had a $0.1 \%$ absolute efficiency gain due to the higher FF. In most of the experiments conducted to confirm the applicability of copper paste in solar cell fabrication, the possibility of a reduction in metallization cost and improved cell performance were achieved by replacing the standard silver printing.

Table 2. Performance of various solar with the passivated copper busbar and gains compared to their reference contact. 


\section{CONCLUTION}

Based on the previous research for IC applications, copper pastes have been developed for solar cells by several institutes and companies. The main issues in developing copper pastes were prohibiting the oxidation of copper during annealing and the diffusion into the silicon substrate. For firing type (glass frit based) copper paste, the copper particles were coated with metal or alloy layers to prevent their diffusion and the oxidation. However, the firing type copper paste still has a greater possibility of diffusion than the curing type (polymer based) copper paste, since the copper particles comes into direct contact with the silicon. In case of the curing type copper paste, diffusion of the copper particles is well blocked, since the surrounding polymer acted as a barrier layer. In addition, the oxidation of copper can be prevented by using a polymer shield or using anti-oxidant copper particles. In reliability tests, such as DHT and TCT, of the copper paste on the solar cells was found to result in a small amount of degradation $(<5 \%)$.

Regarding the curing conditions, the experimental results revealed that an inert atmosphere helped to form a denser copper electrode by restricting the contact between the polymers and the oxygen. However, an inert curing condition requires a great deal of nitrogen gas for purging oxygen in the furnace. At an industrial level, the nitrogen consumption can adversely affect the manufacturing cost of the solar cells. Therefore, finding an optimum curing process for less consumption of nitrogen gas and also, inexpensive coating technique of copper particles need to be further studied.

In summary, when applied to n-PERT structure solar cells, copper paste showed a high potential with $20.7 \%$ conversion efficiency. In addition to the results with the PERT structure, the application of copper paste to HIT solar cells has demonstrated an improved potential, since the ITO layer acts as a barrier layer to prevent copper diffusion at a low curing temperature. Also, the use of copper paste as the passivated busbars requires an additional printing and annealing step after the silver fingers and aluminum rear contact are formed. Accordingly, from an economic point of view, the HIT solar cells have represent a more profitability for the application of the copper paste.

\section{ACKNOWLEDGEMENTS}

This work was supported by the Ministry of Trade, Industry, and Energy, Korea Evaluation Institute of Industrial Technology (KEIT) (No. 10043793) and thank all colleagues at the Green Strategic Energy Research Institute, Department of Electronics Engineering, Sejong University.

\section{REFERENCES}

1. International Technology Roadmap for Photovoltaic (ITRPV) Home Page, http://www.itrpv.net/. Accessed Mar 2016.

2. London Bullion Market Asscociation (LBMA), http://www.lbma.org.uk/home. Accessed 7 Mar 2017.

3. London Metal Exchange Home Page, https:/www.lme.com/metals/non-ferrous/nickel/. Accessed 7 Mar 2017.

4. J. Horzel, Presentation at 5th Workshop on Metallization for Crystalline Silicon Solar Cells, Konstanz, Germany, (2014).

5. A. A. Istratov and E. R. Weber, J. Electrochem. Soc. 149, G21-G30 (2002).

6. S. Brotherton, J. Ayres, A. Gill, H. Van Kesteren, and F. Greidanus, J. Appl. Phys. 62, 1826 (1987).

7. C. Kaimao and W. Zhongan, J. Electron. (China) 5, 285 (1988).

8. E. Schibli and A. Milnes, Mater. Sci. Eng. 2, 173 (1967).

9. S. A. El Rehim, S. Sayyah, and M. El Deeb, Appl. Surf. Sci. 165, 249 (2000).

10. C. Clement, H. Bell, F. Vogg, L. Rebenklau, P. Gierth, and U. Partsch, Energy Procedia 38, 423 (2013).

11. K. Mimura, J.-W. Lim, M. Isshiki, Y. Zhu, and Q. Jiang, Metall. Mater. Trans. A 371231 (2006).

12. J. Zhu, N. Johnson, and C. Herring, Phys. Rev. B 41, 12354 (1990).

13. T. Ogawa, T. Asai, O. Itoh, M. Hasegawa, A. Ikegami, K. Atoh, and T. Kobayashi, IEEE Trans. Compon., Hybrids, Manuf. Technol. 12, 397 (1989).

14. M. T. Barry Edward Taylor, Chie Okabe, Google Patent, (1992).

15. C. Liu, W. Liu, W. Chen, S. Hsieh, T. Tsai, and L. Yang, J. Electrochem. Soc. 152, G234 (2005).

16. D. Wood, I. Kuzma-Filipek, R. Russell, F. Duerinckx, N. Powell, A. Zambova, B. Chislea, P. Chevalier, C. Boulord, and A. Beucher, Energy Procedia 55, 724 (2014).

17. D. Wood, I. Kuzma-Filipek, R. Russell, F. Duerinckx, N. Powell, A. Zambova, B. Chislea, P. Chevalier, C. Boulord, and A. Beucher, Energy Procedia 67, 101 (2015).

18. C. Boulord, P. M. Chevalier, N. E. Powell, and A. P. Zambova, Google Patents, (2012). 
19. J. D. Albaugh, G. D. S. Beaucarne, N. E. Powell, and A. P. Zambova, Google Patents, (2012).

20. G. D. S. Beaucarne, N. E. Powell, L. Tous, D. A. Wood, and A. P. Zambova, Google Patents, (2012).

21. M. Yoshida, H. Tokuhisa, U. Itoh, T. Kamata, I. Sumita, and S. Sekine, Energy Procedia 21, 66 (2012).

22. H. Tokuhisa, S. Ise, S. Morita, S. Tsukamoto, M. Tomita, and M. Yoshida, Jpn. J. Appl. Phys. 54, 08KD22 (2015).

23. D. H. Kim, S. I. Oh, S. K. Kang, B. H. Jun, Y. A. Song, S. J. Kim, and B. J. Chun, Google Patents, (2011).

24. Y. I. Lee, D. H. Kim, J. Y. Kim, J. H. Kwon, and S. E. Kim, Google Patents, (2013).

25. W.-C. Chang, L.-W. Weng, C.-K. Chuang, J.-X. Liang, T.-N. Yang, and W.-Y. Ma, J. Nanosci. Nanotechnol. 16, 9125 (2016).

26. W.-Y. Ma, W.-C. Chang, L.-W. Weng, J.-X. Liang, C.-H. Chung, and T.-N. Yang, Proc. IEEE 43rd Photovoltaic
Specialists Conf. (PVSC), Portland, USA, pp. 2949-2951 (2016).

27. P. Gierth, L. Rebenklau, A. Paproth, H. Bell, C. Clement, F. Vogg, D. Sontag, H. Mehlich, J. Hausmann, and W. Stein, Proc. 28th European Photovoltaic Solar Energy Conf., Paris, France (2013).

28. L. Rebenklau, P. gierth, U. Partsch, H. Mehlich, J. Hausmann, M. Grimm, W. Stein, H. Bell, C. Clement, and F. Vogg, Proc. 27th European Photovoltaic Solar Energy conf., Frankfurt, Germany (2012).

29. T.T. Kyotaro Nakamura, and Yoshio Ohshita, Proc. 31st European Photovoltaic Solar Energy Conf. Hamburg, Germany (2015).

30. S. Yoshiba, M. Dhamrin, M. Yoshida, A. Uzum, U. Itoh, H. Tokuhisa, S. Sekine, T. Saitoh, and K. Kamisako, Proc. 27th European Photovoltaic Solar Energy Conf., Frankfurt, Germany (2012). 